\title{
Mahesh Dattani's Seven Steps Around the Fire : The Plight of Subalterns
}

\author{
Rishi A. Thakar \\ Asst. Prof. \& H.O.D Aroma College of Commerce, Ahmedabad.
}

\begin{abstract}
Theatre is not a mute and mechanical representation of social dynamics. It is a lively representation of the voices resounding in context of totality of human experiences that consciously or unconsciously affect the existing dynamics of human sensibility. Mahesh Dattani has created a niche by giving vent to the frustration and anger of the long suppressed and unrecognized marginalized sections of the society. Reading Dattani's plays is a new kind of experience altogether. Within the framework of dramatic structure, Dattani tries to investigate the identities of those who occupy no space in social order and have been dragged in darkness. Some of the problems his plays deal with have rarely been discussed and recognized in India. Dattani gives an exceptional vehemence to such situations with the fine balance of stage and performance. His plays give a fresh ground as far as themes are concerned. The most charismatic quality of Dattani's plays is the wide range of themes that he deals with in his writing. He depicts mainly the middle-class Indian life and focuses on modern subjects like homosexuality, gender identity, human relationships and communalism. In Seven Steps Around the Fire, Dattani propagates the plight of the subalterns to whom society discards.

The term 'Subaltern' is applied to those of 'inferior rank' (Agrawal 35). By 'Subaltern' Spivak meant the oppressed subjects. In the early 1980s, a collective effort of intellectuals, known as Subaltern Studies Group, started a systematic attempt to study the general attribute of subordination expressed in terms of class, caste, age, gender, office or any other way. Spivak concludes that subalterns are forced to maintain silence against oppression and injustice. Leela Gandhi says,
\end{abstract}

Subaltern studies defined itself as an attempt to allow the 'people' finally to speak within the jealous pages of elitist historiography and in so doing, to speak for, or to sound the muted voice of truly oppressed (Gandhi 2).

The social myths need to be reinvestigated and remoulded to save humanity from chaos. It is essential to have co-ordination between social conventions and consciousness of human dignity. Dattani's social vision seeks a consolation in philosophical arguments. The dramatic mode adopted in Seven Steps Around the Fire comes close to Eliot's observation of drama,

It should remove the surface of things, explore the underneath, or inside of natural surface appearance. ... the indomitable unconscious will and underneath the resolute purpose of the planning animal, the victim of circumstances and the doomed or sanctified being (Eliot 13).

As the note of the play states, Seven Steps Around the Fire was first broadcast as Seven Circles Around the Fire by BBC Radio 4 on $9^{\text {th }}$ January 1999. The play was first performed on stage at the Museum Theatre, Chennai, by MTC Production \& The Madras Players on $6^{\text {th }}$ August 1999. The story of Seven Steps Around the Fire is unusual in the Indian context. Jeremy Mortimer puts it,

For the story he chooses to tell is no ordinary story. The murder victim Kamla, a beautiful hijra eunuch, had, it turns out, been secretly married to Subbu, the son of a wealthy government minister. The minister had the young hijra burned to death, and hastily arranged for his son to marry an acceptable girl. But at the wedding - attended of course by the hijras who sing and dance at weddings and births - Subbu produces a gun and kills himself. The truth behind the suicide is hushed up, but Uma has been keeping full notes for her thesis on the hijra community (Dattani 3).

In order to discuss the play, it is necessary to have some information about the term 'hijra'. Dattani takes care to explain the term 'hijra' by digging up the Indian myth from The Ramayana through Uma's voiceover,

A brief note on the popular myths on the origin of the hijras will be in order, before looking at the class-gender-based power implications. The term hijra, of course, is of Urdu origin, a combination of Hindi, Persian and Arabic, literally meaning 'neither male nor female'. Another legend traces their ancestry to the Ramayana. The legend has it that god Rama was going to 
cross the river and go into exile in the forest. All the people of the city wanted to follow him. He said, 'Men and women turn back.' Some of his male followers did not know what to do. They could not disobey him. So they sacrificed their masculinity, to become neither men nor women, and followed him to the forest. Rama was pleased with their devotion and blessed them. There are transsexuals all over the world, and India is no exception. The purpose of this case study is to show their position in society. Perceived as the lowest of the low, they yearn for family and love. The two events in mainstream Hindu culture where their presence is acceptable - marriage and birth - ironically are the very same privileges denied to them by man and nature (Ibid 10-11).

The plot of Seven Steps Around the Fire is focused around the murder incident of Kamala, a hijra. With this mission, she becomes curious to reveal the mystery of Kamala's murder. The eunuch community usually occupies no honourable space in society and is often pushed back to the margins of society. Uma gets emotionally involved in the whole affair and identifies herself with their suffering.

Uma visits the jail to see Anarkali. Uma addresses Anarkali with pronoun 'She'. Munswamy, a constable, does not recognize the identity of Anarkali as a person and with emphasis uses the pronoun 'it'. He says, "She! Of course it will talk to you. We will beat it up, if it doesn't" (Ibid, 7). In his opinion, the idea of investigating the case of hijra is a waste of time. Even Anarkali is reluctant to Uma's efforts but her love and sympathy gives confidence to Anarkali. Anarkali becomes sentimental and makes confession, "I didn't kill her, she was my sister" (Ibid, 9). The word 'sister' gives an extra force to the need of human touch and interpersonal relationship even at the face of social oddities. Anarkali's helplessness shows a dramatic contrast of the clash of human existence and social expectations. Uma asks her husband Suresh, the reason for putting Anarkali in male prison. Suresh makes very contemptuous remark and tells Uma not to believe them. He has no sympathy for Anarkali and says, "They are all castrated men" (Ibid, 10). In her helplessness, Uma shares the anguish of dramatist to assert that human identity is far above sex determined social identities. Dattani expresses his views on sexuality and says "the purpose of this case study is to show their position in society" (Ibid, 10).

Dattani takes the two sides of argument in the play. First, the apathy of nature - their inability to fulfil sex assigned roles and Second, their misfortune to develop the bonds of human relationship. Anarkali's yearning for relationships suggest that they too have desire for the protection of personal relationships. Anarkali is torn between the fear of social code and legal provisions but finds consolation in the love and sympathy of Uma. Dattani's art is distinct in the sense that he makes representation of Subalterns, defends their cause and stirs awareness in them through the bonds of relationship. Uma and Anarkali represent the dichotomy of margin and centre. Dattani presents the various aspects of subalternity in Seven Steps Around the Fire. If Anarkali is a gendered subaltern, Uma is also a subaltern in comparison to her husband. She has no freedom to spend money according to her own choices, "Even if I wanted to I couldn't explain to my husband why I am paying for your bail" (Ibid, 15). In the process of discovering the pathetic life conditions of Anarkali, she gets entangle in the enigma of her own life.

The action in the play moves in the form of investigation of the case. Uma decides to meet Anarkali's friend and the head of hijras Champa. Uma is nervous and baffled because she is not sure of Champa's response. She offers the bail money to Champa for the bail of Anarkali. Uma suspects that the rivalry between Kamala and Anarkali was the cause of the murder. Salim's intervention brings complication in the play because he is searching for one particular photograph. Champa's confession comes close to Spivak's thesis of 'silence' and 'speech', "We cannot speak ... when we want to speak nobody listens. When we cannot speak ..." (Agrawal 40). Uma tries to stir confidence in Champa to raise voice against the injustice done to them. Uma accuses Champa for the murder of Kamala to awake her conscience. It was difficult for Champa to tolerate and she burst out, "She was my only daughter" (Dattani 28). She confessed that they have equal right for being involved in human relationship and their desires have equal intensity, "You don't know how much we all loved her ! You will not understand. I loved her more than you can love your daughter! You don't know" (Ibid 28). Such irresistible desire for human relationship suggests that eunuchs are not different from other human beings. It makes Dattani to assert that bonds of human relationship are universal beyond the restrictions of myths and conventions. In fact, the socially acceptable relationship of Uma and Suresh seems to be mockery in contrast to irresistible warmth of relationship between Champa and Anarkali for dead Kamala.

In her quest to reveal the mystery of Kamala's murder, Uma maintains the grace of good human being. Her venture no more remains only academic but she develops emotional relationship with Champa and Anarkali. Uma says, "All I know is that if I win their trust, I might get them to talk to me about themselves" (Ibid 28). She inquires about the identity of Salim and his relationship with Kamala at Mr. Sharma's place. The appearance of Subbu, the son of Chief Minister who appears almost by the end of the play, adds complication in the play. Subbu is weak and nervous despite being born and brought up in luxury. Mr. Sharma does not allow 
his son to interact with Uma. In spite of the celebration of marriage he is unhappy, "I hate weddings. I don't want all this! I don't wish to go ahead with this" (Ibid 31) and simultaneously says, "Please, don't arrest Salim. He is a good man" (Ibid 31). This contradiction creates doubt in Uma's mind. Subbu's condition becomes a riddle for her. At this juncture, the action in the play diverts in two distinctive directions - Uma's anguish of her married life and her anxiety about Kamala. The condition of Uma is no better than Kamala and Champa. They at least enjoy their individuality and freedom but Uma has no freedom of choice in her home. In the process of discovering their spaces in the social milieu, she seems to lose her own space.

The last scene of the play is noteworthy for its emotional intensity. Mr. Sharma, the Chief Minister doubts the intentions and purposes of Uma. He is in panic because he is tense about the horrors implied in revelation of the truth. Champa appears for dance with her troup. Mr. Sharma doesn't want them to enter into the main building. Uma here intervens, "No, it is a bad luck to turn away a hijra on a wedding or a birth" (Ibid 38). Champa blesses Uma, "May you have hundred sons" (Ibid 38). As the hijras begin dancing and singing, Subbu comes forward looking at them. The vision of dead Kamala starts haunting Subbu's mind with the dance of Anarkali. Subbu snatches the gun of Suresh in a state of frenzy. He becomes restless to compromise with the restrictions imposed upon him from outside. He becomes blind to all myths and conventions in which he was forced to live, " 'I', I'm leaving you all! You can't keep me away from Kamala" (Ibid 39). Subbu forgets everything and demands the photograph, the last memory of his union with Kamala. Champa gives him the photograph with sympathy, "Give it to him. Take it my son" (Ibid 40). As he looks at the photograph, the present gets suspended and the past gets alive.

In a state of extreme depression, Subbu aims the gun at his father and reveals the secret of Kamala's murder. He cries out, "You killed her?"(Ibid 40). Mr. Sharma who killed Kamala because of her status, pathetically requests Champa to persuade his son to forget Kamala. Subbu takes the gun and shoots himself. With his death, the real mystery of the murder of Kamala starts echoing, "What does it matter, who killed Kamala?" (Ibid 41). The death of Subbu reveals the mystery of murder but makes Uma silent. The reality was so bitter that it was difficult to be exposed in public. The end of the play is little bit depressing but it shows that the 'voice' against oppression is itself a great challenge of life,

They have no voice. The case was hushed up and was not even reported in the newspapers. Champa was right. The police made no arrests. Subbu's suicide was written off as an accident. The photograph was destroyed. So were the lives of two young people (Ibid 42).

As Bijay Kumar Das says, "The play can be interpreted as a protest play against the injustice meted out to the downtrodden in the society" (Bijay Kumar Das 17). In the play Dattani questions the age old belief of marriage being based on heterosexual relationship. He seems to say that homosexual and lesbian relationships being as natural as heterosexual relationship, same-sex marriage should be permitted in India. It is an irony of life that the hijras who are welcome on two occasions - one, at the time of marriage and two, at the time of childbirth - to sing and dance, are themselves deprived of marriage and childbirth. Dattani believes that since in real life there are left-handers, homosexual relationship is as natural as heterosexual relationship. We have to accept the reality of life, however, painful that might be.

Dattani has the power to bring forth the inner-most recesses of human psyche which compels an individual to make struggle against the forces that makes the oddities of life difficult to bear. The distinction of the play lies in strong emotional content and uncompromising yearning for human relationship. Subbu's passion for Kamala is a justification of the fact that 'blood' represents the passion and it is the only authentic realization of human sensibility. It is not a conventional love story but a realization of life beyond the hold of social rituals. It signifies that the subterranean current of sublime realization is beyond the surface of rational control of man. The quest 'to love and live' is the voice of each subaltern. Uma seems to be a defender who tries to articulate the voice of weak. The articulation of the voice of subalterns like Kamala, Anarkali and Champa is possible through the confidence born out of the bonding of human relationship.

\section{Works Cited :}

[1]. Agrawal, Beena Mahesh Dattani's Plays: A New Horizon in Indian Theatre Jaipur : Book Enclave, 2008

[2]. Das, Bijay Kumar Form and Meaning in Mahesh Dattani's Plays New Delhi : Atlantic Publishers and Distributors Pvt. Ltd., 2008

[3]. Dattani, Mahesh Collected Plays New Delhi : Penguin Books India Pvt. Ltd., 2000

[4]. Eliot, T. S. Introduction to Shakespeare and the Popular Dramatic Tradition London : Faber and Faber, 1945

[5]. Gandhi, Leela Post Colonial Theory : A Critical Introduction New Delhi : Oxford University Press, 1998 